\title{
Etnomathematics: A Flat-Build Application of a Quadrilateral in Masjid Agung Pondok Tinggi Kota Sungai Penuh
}

\author{
Selvia Erita ${ }^{1}$ \\ \{selviaerita84@gmail.com $\left.{ }^{1}\right\}$
}

\begin{abstract}
Student of Doctoral Program of Mathematics and Science Education Universitas Jambi Lecturer of Mathematics Education, Faculty of Education and Teacher Training of IAIN Kerinci ${ }^{1}$
\end{abstract}

\begin{abstract}
Mathematics and culture are interrelated to each other, which are found in everyday life. Various mathematical concepts can be explored and found in culture. Mathematical concepts can be seen in cultural products in the form of artifacts such as the Masjid Agung Pondok Tinggi. The Masjid Agung Pondok Tinggi can be a source of learning mathematics, because there are concrete mathematical concepts that are immediately seen by students. The purpose of this research is to explore what concepts exist in the building of Masjid Agung Pondok Tinggi which can be used as a source of learning mathematics and as an effort to develop Etnomathematics in mathematics learning. The Data is collected through exploration, observation, documentation, and literature studies. The results of the study found that in the construction of the Masjid Agung Pondok Tinggi had used mathematical concepts, even though the people in the past did not know how the concept of construction of buildings such as angles, symmetries, rectangles. Construction of the Masjid Agung Pondok Tinggi implements one of the mathematical sciences, namely geometry, one of the concept of a rectangle which includes a square, rectangle, and trapezium. Learning concrete ethnographic objects can facilitate students to understand abstract mathematics.
\end{abstract}

Keywords: Etnomathematics, Build Flat Square, Masjid Agung

\section{Introduction}

Education and culture is something that cannot be avoided in daily life because both of them applies in society, and education is important in society. Culture is a system of values and ideas that are lived by a group of people in a particular environment and in a certain period. Culture is defined as all things related to culture. Culture is having three aspects, namely, first, a universal culture that is related to universal values that apply anywhere that develops in line with the development of people's lives and science or technology. Second, national culture, namely the values that prevail in Indonesian. Third, local culture that exists in the lives of local people (Hadi, 2013).

Education and culture have a very important role in fostering and developing the noble values of our nation, which have an impact on character building based on noble cultural values. As in the Qur'an in the letter Jonah verse 101 mentioned: 


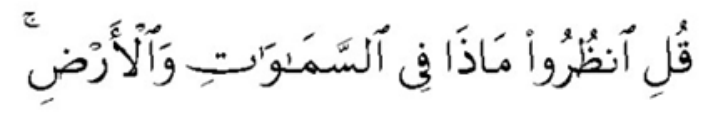

Meaning: "Say, pay attention to what is in heaven and on earth" (Q.S Yunus: 101)

In Qur'an guides human beings to always pay attention and study the natural surroundings, because can learn and acquire knowledge. The understanding of values in mathematics, teachers has not touched all possible aspects. Once it's not wrong, both are true and in accordance with the growth of mathematics.

The purpose of studying mathematics is not only to equip students with conceptual mathematics but to prepare students to be able to solve problems of reasoning and problem solving. In connection with the purpose of learning mathematics, in teaching must be able to construct students' knowledge. Problem Based Learning (PBL) is a recommended approach to be used in improving life skills in the 21st century. Because PBL uses a constructive approach, students are able to think critically in solving mathematical problems, students can master the concepts of matter. Teaching mathematics for each person should be adapted to their culture (D'Ambrosio, 2006).

Astri Wahyuni, et al (2013: 2) said that related between culture and mathematics education isetnomatematics. Ethnomatematics consists of two words, ethno (ethnic / cultural) and mathematics. That means that ethnomatematics is mathematics in culture.

Rosa, Milton et al (2016: 2)reviewmathematics presents the way various cultural groups do their own mathematical reality because it examines how both mathematical ideas and mathematical practices are processed and used in daily activities. Teaching mathematics through cultural relevance and personal experience helps students to learn more about reality, culture, society, environmental problems and themselves by providing real content and mathematical approaches that enable them to master mathematics.

Every culture and sub-culture develops mathematics in their own way. So that mathematics is seen as the result of human reason or mind in the daily activities of society. This concludes that mathematics is a cultural product which is the result of abstraction of the human mind, as well as a problem solving tool. As expressed by Sembiring that mathematics is the construction of human culture (Prabowo and Pramono, 2010).

Relation to Create both culture of mathematics is an important step to recognize various ways of thinking that can lead to various forms of mathematics; This is the field called ethnomatematics. This can mean various mathematical concepts can be explored and found in culture, so it can clarify that mathematics and culture are interrelated, mathematics can be born from culture, mathematics can be excavated in culture so that it can be used as one of the concrete and surrounding sources of mathematics learning.

Ethnomatematics can provide enrichment for the development of new topics that have never been seen by students before, the bias to show students the application of mathematics can be found not only in the fields of science, business, and daily life but students can also see the practice of mathematics cultured throughout the world.

Ethnomatematics objects contain mathematical concepts in a particular society. Ethnomatematic objects can application by traditional games, traditional crafts, artifacts, and activities (actions). The object of ethnomatematics study is obtained in two ways, namely: (1) Investigating the mathematical activities that exist in certain groups, (2). Express the mathematical concepts contained in these activities.

Cultural products in the form of artifacts such as building architecture, carved furniture, songket which originally had a motif or ornament that has been standardized were given the 
opportunity to be developed through mathematical creative thinking. One of the artifacts in the form of a historic building in Kota Sungai Penuh (Kerinci) is Masjid AgungPondok Tinggi, one of the oldest mosques in the Kerincidistrict, Sungai Penuh in Jambi Province. The mosque, built in 1874, is a real witness of the spread of Islam.

The location of Masjid Agung Pondok-Pondok Tinggi in RT 02 Desa Pondok Tinggi, Sungai Penuh. The architecture of the Masjid Agung Pondok Tinggi was built following the architectural model of the original archipelago mosque with the characteristics of three tumpeng pyramid roofs, the upper part decorated with crescent and star emblems. In building ofMasjid AgungPondok, people have used mathematical concepts, even though people in the past did not know the construction of buildings such as angles, symmetries, rectangles. But they can build magnificent and resistant buildings lama.

The uniqueness of Masjid Agung Pondok Tinggi is having a tower inside building. Inside the mosque there is a place for the muazin to azan. It has a design that is typical of ancient Indonesian mosques, with classical architecture and also various carvings of various motifs. The entire construction of the Masjid Agung does not use nails or iron. Masjid Agung walls made of wood are also installed with a pipe in such a way that it is shock resistant.

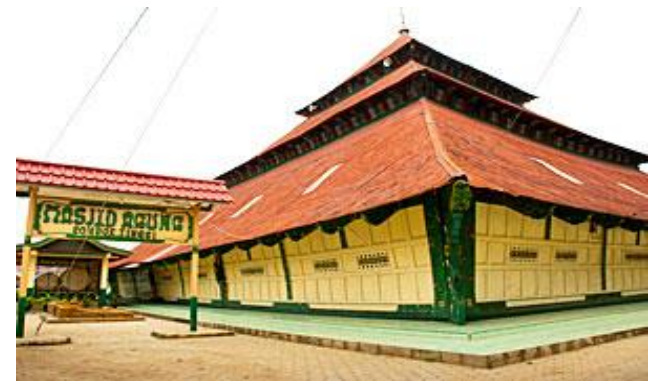

Fig. 1. Masjid Agung Pondok Tinggi

Based on the above description of the relationship between mathematics and culture and cultural potential in the approach to mathematics learning, the research aimedto exploring ethnomathematics in Masjid Agung Pondok Tinggi.

\section{Research Methods}

This study uses explorative research with an ethnographic approach at Masjid Agung Pondok Tinggi. The study was conducted in four stages, namely exploration, observation, documentation, and literature study. Exploration, observation and documentation were carried out to find the shape of a quadrilateral flat in Masjid Agung Pondok Tinggi. While the literature study was carried out to analyze the concept of quadrilateral flat at Masjid Agung Pondok Tinggi. To ensure the level of trust in the data is done in several ways, namely conducting intensive observation, data triangulation and methods and preparing references. 


\section{Results And Discussion}

The concept of mathematics as a result of the activity of designing buildings, measuring, making patterns, and counting can be revealed from the making of the mosque. Mathematical concepts in development, even though the people of Sungai Penuh in the past did not know the basic material of building construction in formal education (such as the concept of angles, symmetries, rectangles, and other geometrical concepts).

Construction of the Masjid Agung Pondok Tinggi has implemented one of the mathematical sciences, namely geometry in the construction of building parts, one of which is a rectangular flat, covering a square, rectangle, trapezium, and rhombus. The space-building model includes the cube, the mathematical model includes symmetrical properties. In this study, researchers only examined the rectangular flat construction.

Based on the results of exploration, observation and documentation, the Masjid Agung Pondok Tinggi has several rectangular shapes. in this discussion presented a rectangular flat shape in the Masjid Agung Pondok Tinggi, and a mathematical concept that explains these forms.

Masjid Agung Pondok Tinggimeasuring is 30 x 30 meters with a height of 3.5 meters. The mosque is equipped with 2 entrances. Mihrab mosque is square. Supported by 36 supporting poles. The 36 pillars were divided into 3 groups of poles, namely tiang panjang Sembilan (tiang tuo), tiang panjang limau (panjang lima), dan tiang panjang duea (tiang panjang dua).

The columns are arranged according to their size, composition, and location. Tiang panjang Sembilan (tiang tuo), as many as four pieces arranged to form a rectangle located in the inner room. The pole was given gold nails to refuse reinforcements and at the top was given a red and white cloth as a symbol of glory. Tiang panjang limau (panjang lima) as many as 8 pieces arranged to form a rectangle and these poles are located in the middle room. Meanwhile, 24 lengths of tiang panjang duea (tiang panjang dua) were arranged to form a rectangle and located in the outer room. the building of the Masjid Agung Pondok Tinggi Consists of wooden structures.

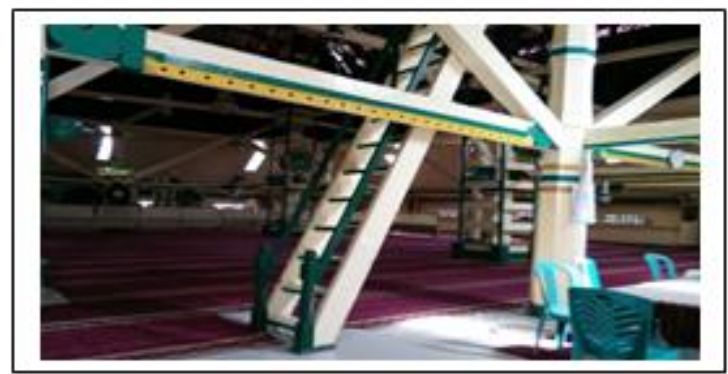

Fig. 2. The pillars of the buffer of the Masjid Agung Pondok Tinggi.

A. Types of Build Flat The square used in the Masjid Agung Pondok Tinggi, and relation of Two-dimentional figure Concept

1. ROOF OF MASJID AGUNG

This Masjid Agung of high hut is roofed with three layers which are increasingly upward and pointed in a pyramid shape, in the high hut language "Bapucouk Satau, Barampek Jure, Batingkat Tigea" which symbolizes the government structure of Pondok Tinggi. Based on the 
results of interviews with the traditional leaders of the Bapucouk Satau high cottage, it means kepala adat yaitu Depati Payung nan Sakaki, Satu Kepala Syarak and symbol Allah. Keatas satu pucuk kebawah satu urat. Barampek Jure means empat luhah (lurah), empat Rio (ninik mamak), empat pegawai, and Bapingkat Tigea (bertingkat tiga) means sko nan tiga, sko depati berjenjang naik dan bertanggaturun.

The roof of the Masjid AgungPondok Tinggi can be modeled geometrically, that is, on a single-storey roof consisting of 4 equilateral triangles, level 2 and 3 trapezoidal

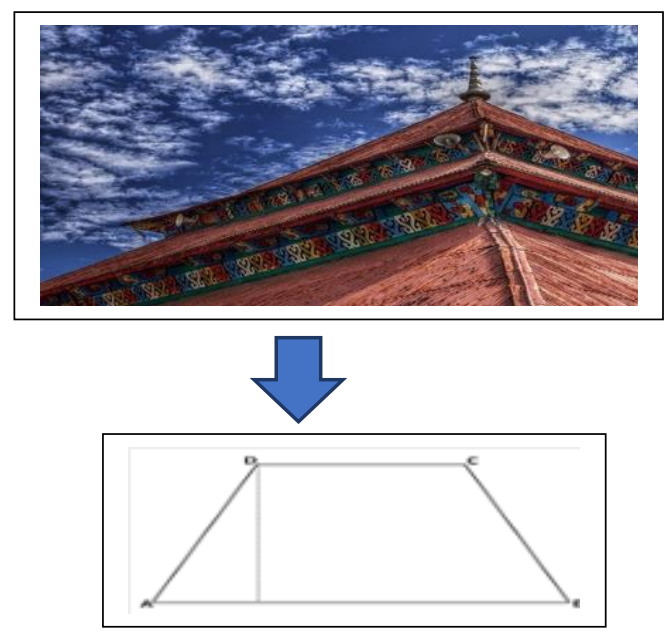

Fig. 3. Geometry Modeling root of Masjid Agung Pondok Tinggi

Picture above describe that modeling in the form of a flat building that has four sides. The researchers analyzed concept of quadrilateral on the roof of the Masjid Agung Pondok Tinggi

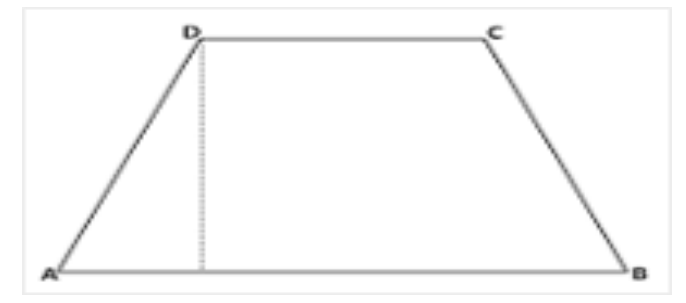

Fig. 4. Trapezoidal Concept on the Roof of the Grand Mosque of Pondok Tinggi

Based on the analysis in Figure 4, it can be concluded that there is a trapezoidal concept on the roof structure of the mosque. The trapezoidal properties that can be found in roof modeling according to Figure 3 are as follows:

1) $\mathrm{AB} / / \mathrm{CD}$ (a pair of sides)

2) The number of angles adjacent between two parallel sides is $180^{\circ}(\mathrm{m}<\mathrm{A}+\mathrm{m}<\mathrm{D}=1800$ $; \mathrm{m}<\mathrm{B}+\mathrm{m}<\mathrm{C}=1800$ ) 


\section{Wall Of Masjid Agung}

On the walls of Masjid Agung Pondok Tinggi havesquareand rectangular concepts in theconstruction. The uppermost part of the first row of the walls is composed of several rectangular pieces, the middle (second) section of the wall is square in shape interspersed with floral motifs and the lowest part of the wall is composed of several rectangular pieces.
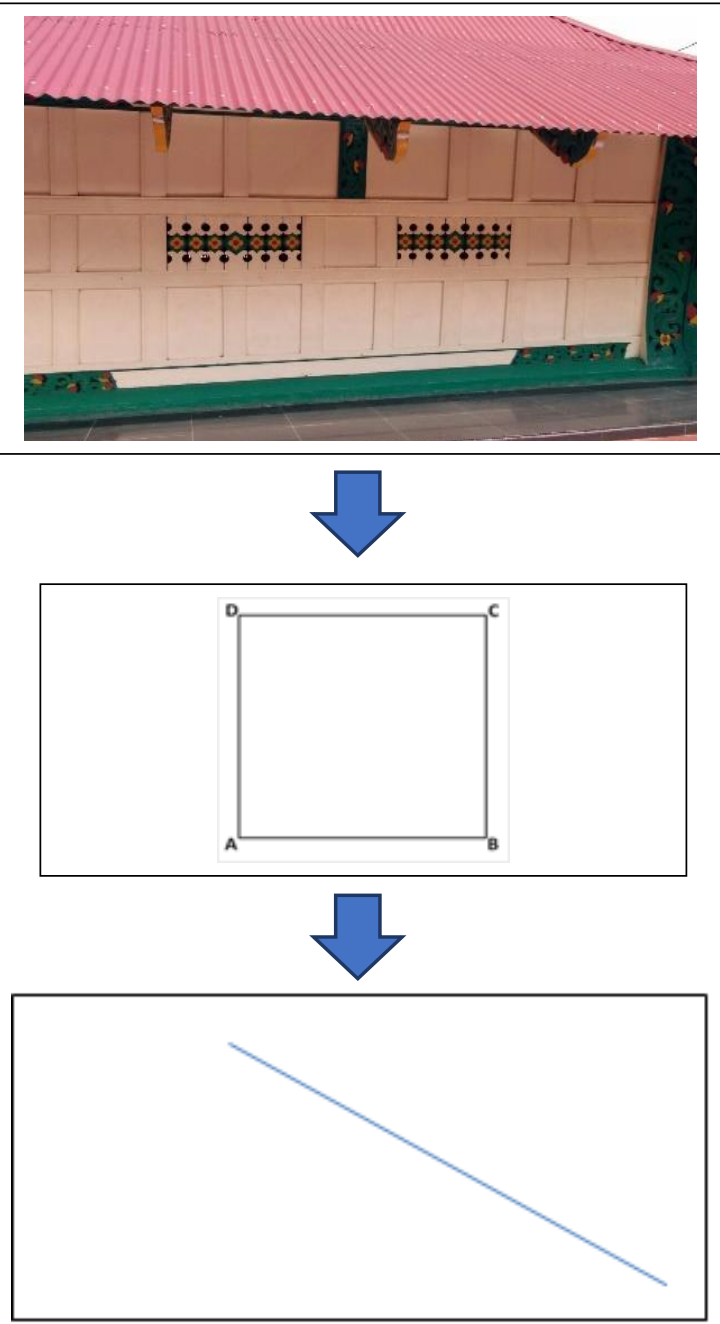

Fig. 5. Geometry Mode ling on the walls of the Pondok Tinggi Grand Mosque

The wall in Figure 5 can be modeled geometrically as in the bottom part of Figure 6 . From the figure, describe that modeling of the a flat building that has four sides.Based on this, the researcher further analyzed the concept of quadrilateral on the wall (Figure 6).

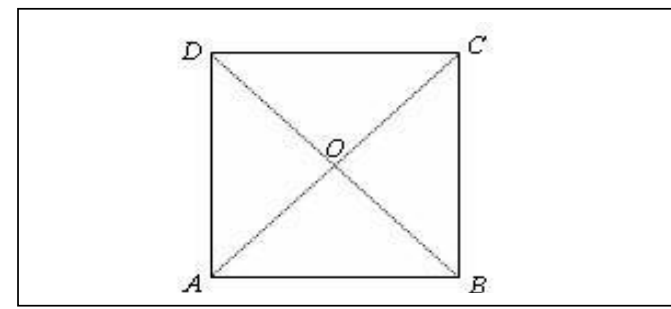


Fig. 6. Square Concepts on the walls of the Grand Mosque of Pondok Tinggi

Based on the analysis in Figure 6, it can be concluded that there is a concept of square on the wall. The square properties that can be found in the wall modeling in Figure 2 are as follows:

1) $\mathrm{AB}=\mathrm{BC}=\mathrm{CD}=\mathrm{AD}$

2) $\mathrm{m}<\mathrm{A}=\mathrm{m}<\mathrm{B}=\mathrm{m}<\mathrm{C}=\mathrm{m}<\mathrm{D}=900$

3) $\mathrm{AO}=\mathrm{OC}=\mathrm{BO}=\mathrm{OD}$

4) It has four rotating symmetries and four fold symmetries, so it can occupy its frame in 8 ways

Besides being square, walls of Masjid Agung Pondok Tinggi describe ofgeometricallymodeled that concluded a rectangular concept on severalwalls (Figure 7).

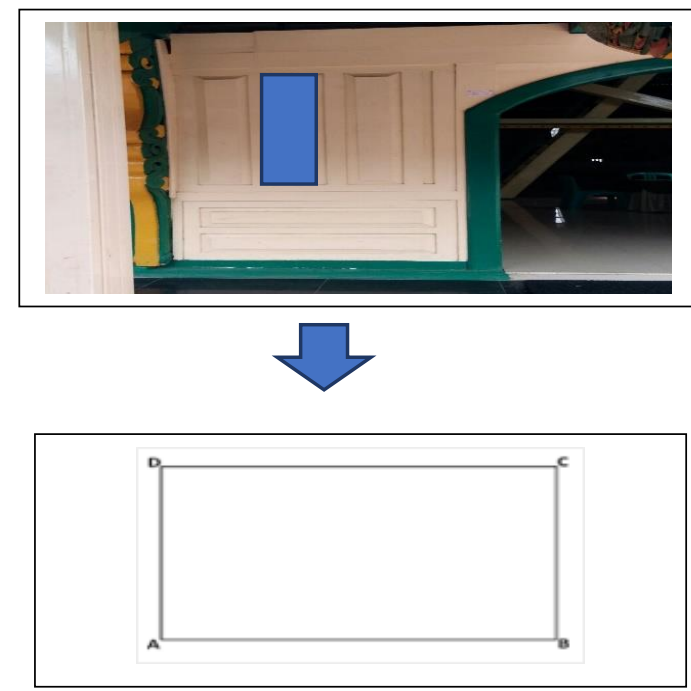

Fig. 7. Geometry Modeling on the walls of the Pondok Tinggi Grand Mosque

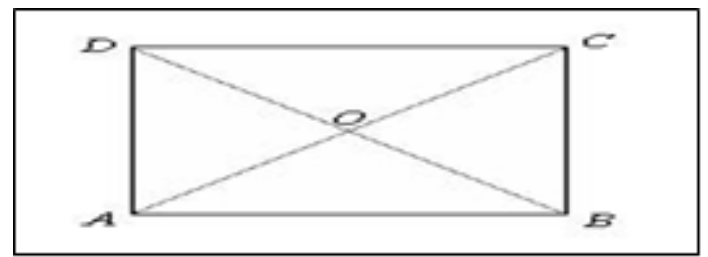

Fig. 8. Rectangular Concepts ofMasjid Agung Walls

Based on the analysis in Figure 8, it can be concluded that there is a concept of a rectangle on the wall of Masjid Agung. The properties of rectangles that can be found in Masjid Agung wall modeling are as shown in Figure 8, as follows:

1) $\mathrm{AB}=\mathrm{CD} ; \mathrm{BC}=\mathrm{AD}$

2) $\mathrm{m}<\mathrm{A}=\mathrm{m}<\mathrm{B}=\mathrm{m}<\mathrm{C}=\mathrm{m}<\mathrm{D}=900$

3) $\mathrm{AO}=\mathrm{OC}=\mathrm{BO}=\mathrm{OD}$, maka $\mathrm{AC}=\mathrm{BD}$ 
4) Has 2 rotating symmetries and 4 folding symmetries so that they can occupy the frame in 4 ways.

Other parts of Masjid Agung Pondok Tinggi also have a rectangular concept. Some of them are the concept about rectangle on the door of Masjid Agung. The rectangular arrangement found on the mosque door can be seen as shown below:

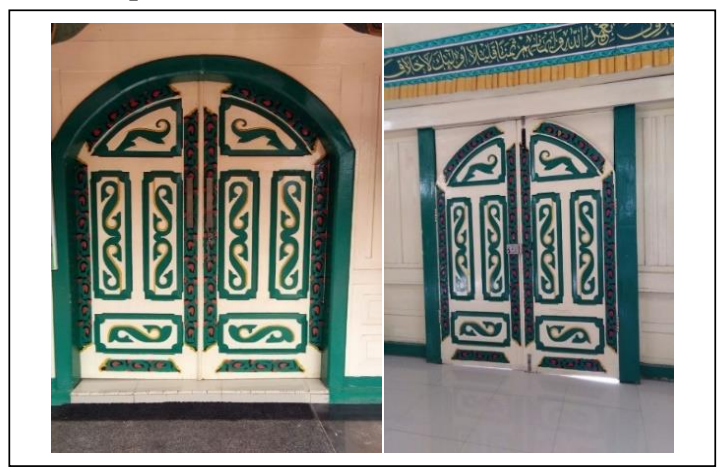

Fig. 9. Entrance to the Pondok Tinggi Great Mosque Looks Outside and Inside

\section{Floor Of The Mosque}

Floor on Masjid Agung Pondok Tinggi as been renovated using a square ceramic floor. The square arrangement on the floor already uses a square concept as described on the wall of the Masjid Agung .

B. Utilization of Ethnomatemics at Masjid AgungPondok Tinggi in Learning

Based on the explanation that has been explained, it can be said that the rectangular flat buildings contained in the construction of Masjid AgungPondok Tinggi can be used in the learning process carried out by the teacher in the classroom, besides as a medium for learning especially quadrilateral material. Problem Based Learning Approach,by using media that can be directly seen by students can facilitate the understanding of students and provide opportunities for students to express ideas on solving a problem in completing the task given by teacher.

Some rectangular shapes in building construction can be used as media to use principles such as angle, side length, right angle, symmetry and so on. Students can also be asked to identify any geometry built in Masjid Agung Pondok Tinggi.

\section{Conclusion}

Quadrangular flat building is a flat build model that is limited by 4 segments. The mathematical concept of Masjid Agung Pondok Tinggi consists of square, rectangle and trapezoid. Teachers can utilize flat forms in Masjid Agung Pondok Tinggi as concrete learning resources. Quadrilateral flat shape can be an alternative source of learning mathematics for students. In addition students can obtain knowledge related to geometric concepts, especially in quadrilateral material. Increasing motivation in learning and facilitating students in linking concepts learned with real-world situations. 


\section{References}

[1] Astri Wahyuni, Ayu Aji W T, dan Budiman Sani.: Peran Ethno matematika ,Makalah dipresentasikan dalam Seminar Nasional Matematika dan Pendidikan Matematika dengan Tema "Penguatan Peran Matematika dan Pendidikan Matematika untuk Indonesia yang Lebih Baik" pada Tanggal 9 November 2013 di Jurusan Pendidikan Matematika FMIPA UNY (2013)

[2] D'Ambrosio, U.: Ethnomathematics: Link Between Traditions and Modernity. Rotterdam: Sense Publisher (2006)

[3] Hadi Kasmaja.: Sebuah Ide Penelitian Matematika Dalam Perspektif Lokalitas Budaya. (2013)

[4] Marsigit.: Pengembangan Pembelajaran Matematika Berbasis Etnomatematika.Makalah dipresentasikan pada : Seminar Nasional Matematika dan Pendidikan Matematika 2016 dengan Tema : Etnomatematika, Matematika dalam Perspektif Sosial dan Budaya, Prodi Pendidikan Matematika STKIP Sumatera Barat, Sabtu/16 April (2016)

[5] Prabowo, A., dan Pramono, S.: Memahat Karakter Melalui Pembelajaran Matematika. Internasional Conference On Teacher Education. Bandung (2010)

[6] Rosa, M. dan Orey, D.C.: Ethnomatematics: The Cultural Aspect of Mathematics. Revistas Latinoamericana De Etnomatematica, Vol. 4 No 2 hlm. $32-54$ (2011)

[7] Rosa, M. Dan Orey, D.C.: Current and Future Perspectives of Etnomatthematics as a Program. Hamburg. Spinger (2016) 